\title{
KNOWLEDGE, ATTITUDE AND PRACTICE OF EPILEPSY AMONG UNDERGRADUATE MEDICAL AND NURSING STUDENTS IN RAJASTHAN
}

\author{
R. K. Sureka1 , Sharad Saxena' ${ }^{2}$ Puneet Rijhwani3 ${ }^{3}$ Surbhi Chaturvedi ${ }^{4}$, Abhishek Charan ${ }^{5}$ \\ 1 Professor and HOD, Department of Neurology, Mahatma Gandhi Medical College, Jaipur. \\ ${ }_{2}^{2}$ Postgraduate Resident, Department of General Medicine, Mahatma Gandhi Medical College, Jaipur. \\ 3 Professor and HOD, Department of General Medicine, Mahatma Gandhi Medical College, Jaipur \\ ${ }_{4}^{4}$ Resident, Department of Neurology, Mahatma Gandhi Medical College, Jaipur. \\ ${ }_{5}^{5}$ Postgraduate Resident, Department of General Medicine, Mahatma Gandhi Medical College, Jaipur.
}

\section{ABSTRACT}

\section{BACKGROUND}

Aim of this study is to assess and compare knowledge, attitude and practice amongst nursing students and MBBS students in a tertiary care centre.

\section{MATERIALS AND METHODS}

All participants completed the self-administered questionnaire after signing the consent to participate in the study. A questionnaire was designed to test the knowledge on aetiology and treatment, attitude in dealing with persons with epilepsy and familiarity with various forms of treatment and management. Possible difference in answers were analysed amongst nursing and MBBS students.

\section{RESULTS}

Majority of students with both groups had heard about epilepsy. Around 40\% of MBBS students in comparison to nursing students approx. $27 \%$ believed that epilepsy is a mental illness. Around $76 \%$ of nursing students in comparison to MBBS students approx. $50 \%$ believed that epilepsy creates hindrance in normal life. Majority of individuals think that epilepsy is curable. More than $75 \%$ of participants in both groups had opinion that epilepsy can be treated with allopathic medicine.

\section{CONCLUSION}

Lots of superstition and misbelief exists amongst health care providers. Present study also depicts the same.

\section{KEYWORDS}

Knowledge, Attitude, Practice, Epilepsy

HOW TO CITE THIS ARTICLE: Sureka RK, Saxena S, Rijhwani P, et al. Knowledge, attitude and practice of epilepsy among undergraduate medical and nursing students in Rajasthan. J. Evolution Med. Dent. Sci. 2016;5(98):7166-7169, DOI: $10.14260 /$ jemds/2016/1622

\section{BACKGROUND}

Epilepsy is one of the commonest neurological disorders with marked sociocultural stigma. ${ }^{1}$ Epilepsy afflicts 50 million people all over the world, almost $80 \%$ of whom belong to developing countries and nearly three fourths of these patients do not receive the appropriate treatment. ${ }^{2}$ Further studies have reported the global incidence of epilepsy to be generally between 5 to 10 cases per 1000 people. The all inclusive rate includes the incidence of 50 people per 100,000 persons and these incidences are multifactorial that vary according to the seizure types, seizure presentation and antiepileptic drugs administered. ${ }^{3}$ It is estimated that there are more than 10 million persons with epilepsy in India. Its prevalence is about $1 \%$ in our population. ${ }^{4}$ The prevalence is higher in the rural $(1.9 \%)$ compared to urban population $(0.6 \%) .5,6$ In developing countries like India, lots of

Financial or Other, Competing Interest: None.

Submission 03-09-2016, Peer Review 01-10-2016,

Acceptance 07-10-2016, Published 07-12-2016.

Corresponding Author:

Dr. Rajendra Kumar Sureka,

\#47, Sanjay Marg,

Hathroi Scheme,

Jaipur, Rajasthan.

E-mail: rsureka@rediffmail.com

DOI: $10.14260 /$ jemds/2016/1622

superstitions, discriminations, and stigmata are associated with this disease. Students in a medical fraternity would be one of the primary sources of information as doctors in the future and thus it is important that these future health care professionals be well informed about epilepsy and take an appropriate attitude towards the disease. Thus, the study was conducted to evaluate the knowledge and attitude on epilepsy amongst nursing students (GNM and B.Sc) and MBBS students (first year and final year) with the aim to assess the level of knowledge and attitudes on epilepsy which may help in planning awareness programme for them.

\section{MATERIALS AND METHODS}

The study was carried out in the Department of Neurology at Mahatma Gandhi Medical College and Hospital Jaipur. A questionnaire designed to test the knowledge, attitude and practice regarding epilepsy was used. The questionnaire was distributed to Nursing students $(n=211)$, group A out of which 133 belong to GNM and 78 belong to B.Sc students and MBBS students $(\mathrm{n}=200)$, group $B$ out of which 100 belong to first year MBBS students and 100 belong to final year students, who volunteered to participate in this study. Most of the questions in the instrument have already been used by other researchers. ${ }^{[7,8]}$ 


\section{RESULTS}

411 participated $(\mathrm{n}=211)$ in group A (GNM 133 and B.Sc students 78) and $n=200$ in group B (first year 100 and final 100 Students).

\section{KNOWLEDGE}

Among both groups, most of them had heard about epilepsy and majority of participants in both groups believe epilepsy is an organic brain problem. Concerning the causes of epilepsy around $27 \%$ of participants thought epilepsy is a mental illness, the proportion is $40 \%$ in group B participants. It is observed that $25 \%$ of participants in group B consider birth defect and blood disorder as a cause of epilepsy.

Around 55-58\% of participants (Group A) labelled loss of consciousness and convulsions as epilepsy. In this survey, it came out that family history was present in around $21-39 \%$ in both groups. Supernatural power as a cause was enumerated by $5 \%$ of nursing students.

\section{ATTITUDE}

Majority (76\%) of participants of group A considered epilepsy as hindrance in life and 33\% think epileptic person should not marry, and around $50 \%$ of participants of group B considered epilepsy as a hindrance in life and $25 \%$ think epileptic person should not marry. Among both groups, majority of participants would like to play/study with epileptic child. Regarding the first aid on seeing the epileptic attack, majority of members in both groups would take patient to the hospital and about $16 \%$ in group A members would like to put water/shoe/onion on face and around $23 \%$ in group A participants thought epileptics have committed sins in past life.

\section{PRACTICE}

It is observed that $86 \%$ of participants in group A thought that epilepsy is curable. Majority of participants in both groups considered epilepsy can be treated with allopathic medicine, followed by ayurvedic and homeopathic treatment (40-50\%) by group B participants. Both groups were of view that an epileptic patient needs lifelong treatment (32-44\%) and around $50 \%$ participants in both groups thought drugs used in epilepsy would have many side effects. If we talk about treatment compliance, $50 \%$ in both groups have knowledge that patients should not miss even a single dose.

\begin{tabular}{|c|c|c|c|c|c|}
\hline \multirow[t]{2}{*}{$\begin{array}{l}\text { Sl. } \\
\text { No. }\end{array}$} & \multirow[t]{2}{*}{ Questions } & $\begin{array}{c}\text { NURSING } \\
\text { STUDENTS } \\
\text { (Group-A) } \\
n=211\end{array}$ & \multirow[t]{2}{*}{$\%$} & $\begin{array}{c}\text { MBBS Students } \\
\text { (Group-B) } \\
\mathbf{n}=\mathbf{2 0 0}\end{array}$ & \multirow[t]{2}{*}{$\%$} \\
\hline & & YES & & YES & \\
\hline 1 & Have you ever heard of epilepsy? & 164 & 77.73 & 174 & 87 \\
\hline 2 & Do you know a person suffering from epilepsy? & 63 & 29.86 & 50 & 25 \\
\hline 3 & Is epilepsy an organic brain problem & 123 & 58.29 & 119 & 59.5 \\
\hline 4 & Is epilepsy known to occur in family & 46 & 21.8 & 78 & 39 \\
\hline 5 & Can epilepsy spread by contact? & 10 & 4.74 & 1 & 0.5 \\
\hline 6 & What do you think is the cause of epilepsy? & & & & \\
\hline $\mathrm{a}$ & Don't know & 11 & 5.21 & 34 & 17 \\
\hline $\mathrm{b}$ & Organic brain disease & 115 & 54.5 & 118 & 59 \\
\hline c & Mental Illness & 58 & 27.49 & 81 & 40.5 \\
\hline $\mathrm{d}$ & Birth defect & 53 & 25.12 & 5 & 2.5 \\
\hline $\mathrm{e}$ & Evil spirit & 2 & 0.95 & - & - \\
\hline $\mathrm{f}$ & Super natural cause & 12 & 5.69 & 3 & 1.5 \\
\hline $\mathrm{g}$ & Blood disorder & 54 & 25.59 & - & - \\
\hline $\mathrm{H}$ & other (please specify) & & & & \\
\hline 7 & What do you think an epilepsy attack is? & & & & \\
\hline A & $\begin{array}{l}\text { Convulsion } \\
\end{array}$ & 118 & 55.92 & 86 & 43 \\
\hline B & Loss of consciousness & 124 & 58.77 & 49 & 24.5 \\
\hline $\mathrm{C}$ & Mental attack & 20 & 9.48 & 37 & 18.5 \\
\hline $\mathrm{D}$ & Behavioural change & 36 & 17.06 & 14 & 7 \\
\hline E & Period of amnesia & 42 & 19.91 & 11 & 5.5 \\
\hline $\mathrm{F}$ & other (please specify) & 14 & 6.64 & - & - \\
\hline 8 & You know about epilepsy from? & & & & \\
\hline A & Studies & 141 & 66.82 & 81 & 40.5 \\
\hline B & Researched about it & 23 & 10.9 & 1 & 0.5 \\
\hline $\mathrm{C}$ & Attended an epilepsy camp & 73 & 34.6 & 1 & 0.5 \\
\hline $\mathrm{D}$ & Yourself have it & 18 & 8.53 & - & - \\
\hline E & Some family member or friend has it & 32 & 15.17 & 21 & 10.5 \\
\hline $\mathrm{f}$ & Through television/internet ads & 65 & 30.81 & 26 & 13 \\
\hline \multicolumn{6}{|c|}{ Table 1: Knowledge of Epilepsy } \\
\hline
\end{tabular}




\begin{tabular}{|c|c|c|c|c|c|}
\hline \multirow[t]{2}{*}{$\begin{array}{c}\text { Sl. } \\
\text { No. }\end{array}$} & \multirow[t]{2}{*}{ Questions } & $\begin{array}{c}\text { NURSING } \\
\text { STUDENTS } \\
\text { (Group-A) } \\
\mathbf{n = 2 1 1} \\
\end{array}$ & \multirow[t]{2}{*}{$\%$} & $\begin{array}{c}\text { MBBS } \\
\text { Students } \\
\text { (Group-B) } \\
\mathbf{n = 2 0 0} \\
\end{array}$ & \multirow[t]{2}{*}{$\%$} \\
\hline & & YES & & YES & \\
\hline 1 & Epilepsy creates hindrance in normal life & 161 & 76.3 & 100 & 50 \\
\hline 2 & A person with epilepsy should not marry & 70 & 33.18 & 5 & 2.5 \\
\hline 3 & A person with epilepsy will not have normal sexual relations & 100 & 47.39 & 3 & 1.5 \\
\hline 4 & A person with epilepsy should not study & 67 & 31.75 & 1 & 0.5 \\
\hline 5 & A person with epilepsy should not work & 71 & 33.65 & 2 & 1 \\
\hline 6 & Society should behave differently with a person with epilepsy & 64 & 30.33 & 18 & 9 \\
\hline 7 & Would you like to play/study with an epileptic child? & 168 & 79.62 & 167 & 83.5 \\
\hline 8 & If you see a person having epileptic attack what will you do? & & & & \\
\hline $\mathrm{a}$ & Put shoe/onion on his/her face & 35 & 16.59 & 11 & 5.5 \\
\hline $\mathrm{b}$ & Place bunch of keys in his/her hand & 1 & 0.47 & 1 & 0.5 \\
\hline $\mathrm{c}$ & Take him/her to hospital & 143 & 67.77 & 138 & 69 \\
\hline $\mathrm{d}$ & Put water on his/her face & 21 & 9.95 & 16 & 8 \\
\hline e & Other (please specify) & 75 & 35.55 & - & \\
\hline 9 & Have epileptics committed sins in the past life? & 49 & 23.22 & 9 & 4.5 \\
\hline \multicolumn{6}{|c|}{ Table 2: Attitude towards Epilepsy } \\
\hline
\end{tabular}

\begin{tabular}{|c|c|c|c|c|c|}
\hline \multirow[t]{2}{*}{$\begin{array}{c}\text { Sl. } \\
\text { No. }\end{array}$} & \multirow[t]{2}{*}{ Questions } & $\begin{array}{c}\text { Nursing } \\
\text { Students } \\
\text { (Group-A) } \\
\mathrm{n}=\mathbf{2 1 1}\end{array}$ & \multirow[t]{2}{*}{$\%$} & $\begin{array}{c}\text { MBBS } \\
\text { Students } \\
\text { (Group-B) } \\
n=200\end{array}$ & \multirow[t]{2}{*}{$\%$} \\
\hline & & Yes & & Yes & \\
\hline 1 & Can epilepsy be treated with Allopathic medicine? & 168 & 79.62 & 154 & 77 \\
\hline 2 & Can epilepsy be treated with Homoeopathic medicine? & 154 & 72.99 & 80 & 40 \\
\hline 3 & Can epilepsy be treated with Ayurvedic medicine? & 173 & 81.99 & 102 & 51 \\
\hline 4 & Is Ayurvedic treatment the only option for epilepsy? & 19 & 9.01 & 13 & 6.5 \\
\hline 5 & Does an epileptic patient need lifelong treatment? & 68 & 32.23 & 89 & 44.5 \\
\hline 6 & A person with epilepsy should not miss even a single tablet & 131 & 62.09 & 98 & 49 \\
\hline 7 & Drug used in epilepsy will have many side-effects & 112 & 53.08 & 99 & 49.5 \\
\hline 8 & Tantric (holy) treatment is good for epilepsy & 57 & 27.01 & 8 & 4 \\
\hline 9 & Priest can treat epilepsy better? & 47 & 22.27 & 3 & 1.5 \\
\hline 10 & Can epilepsy be cured? & 182 & 86.26 & 137 & 68.5 \\
\hline \multicolumn{6}{|c|}{ Table 3: Practice in Epilepsy } \\
\hline
\end{tabular}

Note- "n" denotes total number of subjects in a particular category and data in "( )" represents \% out of total number in that category.

\section{DISCUSSION}

The study shows knowledge, attitude and practice amongst medical students (200) and nursing students (211).

\section{KNOWLEDGE}

Most of the participants from both the groups had heard about epilepsy. Group A (Nursing Students) had heard about epilepsy $(77.73 \%)$ through studies, journals and newspaper. In similar studies from Italy (96.0\%), ${ }^{9}$ Canada (91.0\%), ${ }^{10}$ Brazil (91.3\%),11 Malaysia (86.5\%), ${ }^{12}$ participants had heard about epilepsy. And $87 \%$ of medical students (group B) had heard about epilepsy. Similar studies from Jordan ${ }^{13}$ and Malaysia $^{12}$ showed that around $77.6 \%$ of medical students had heard about epilepsy. In group B, 25\% of students knew someone (members and friends) suffering from epilepsy while $46 \%$ students from a study in Southern Nigeria had witnessed persons with epilepsy. We think it is probably due to increase in awareness on epilepsy which helps them to recognise as compared to our studies. Around 54\% of group A participants considered epilepsy is an organic brain disease, $27 \%$ thought as mental illness and $25 \%$ thought as a birth defect/blood disorder and supernatural cause was enumerated by $5 \%$ of nursing students followed by evil spirit $0.95 \%$.

Whereas $59 \%$ of group B participants thought epilepsy is an organic brain disease, $40 \%$ thought as mental illness. A similar study from Malaysia 12 showed $39.7 \%$ of the undergraduate students stated that epilepsy is a form of mental illness. This reflects the level of misconception and stigma associated with epilepsy in nursing students as compared to MBBS students.

\section{ATTITUDE}

Misconception about epilepsy is widely prevalent in developing regions. In our study, $76 \%$ of participants in group A thought epilepsy creates hindrance in life as compared to group B i.e. $50 \%$. It is surprising to know that $33 \%$ of participants of group A thought that an epileptic person should not marry and $47 \%$ thought that they cannot have normal 
sexual relationship and around 30\% thought an epileptic person should not work/play. While in group B, 1-2\% thought epileptic person should not marry/study/work. Our study shows that misconception about epilepsy in nursing students is much more and it needs to be taken care of by spreading awareness about epilepsy. Most negative attitude towards a person with epilepsy was from Jordan where students refused to marry $(50.5 \%)$ and children with epilepsy would have disability (44.4\%). ${ }^{13}$ The mistaken belief of putting shoe/onion on an epileptic person's face, placing bunch of keys in hands or other practices has been observed in more than $16 \%$ of students (Group A). In a study by Falavinga A et al,14 these mistaken ideas were observed in $38.8 \%$ of the sample. Another Brazilian study ${ }^{11}$ demonstrated that $71 \%$ of the first year students of health care related disciplines and $32 \%$ of the last year students follow these practices.

\section{PRACTICE}

It is encouraging to know that around 78\% participants in both groups were of view that allopathic medicine is the major stay of treatment for epilepsy. Group A participants believed that epilepsy could be treated with homeopathic (72\%) and ayurvedic (81\%) treatment. Whereas in group B, 40\% thought epilepsy can be treated with homoeopathic medicine and $50 \%$ thought epilepsy can be treated with ayurvedic medicine. Most Indians have an abiding faith in the indigenous Ayurvedic form of treatment. Another reason for popularity of Ayurvedic medicines is the easy accessibility to practitioners of the system, especially in rural India. It is surprising in a study from medical community [Northern Nigeria] where majority of respondents $(47 \%)$ opted for spiritual methods. This was followed by orthodox (34\%) and use of traditional herbal medicines $(19 \%)$ for treating epilepsy. 15 The use of spiritual healing is even worse in the study, most commonly reported treatment methods were - holy Quran (71.4\%), medication $(71.3 \%)$ and herbs $(29.3 \%)^{15}$. In a study of medical students of Southern Nigeria around $47.9 \%{ }^{16}$ would take them to church while some of the health care persons would put some object in mouth to protect the tongue. Whereas in our study, around $22 \%$ participants of groups A would take the person to a priest and around $27 \%$ would take the person to a tantric. Around $50 \%$ of participants in both groups believed that missing a dose of their antiepileptic drug results in an epileptic attack. These data suggest lack of information about assistance and safe handling of seizures in these health care courses.

\section{CONCLUSIONS}

The study shows that the nursing students and MBBS students were familiar with epilepsy. But major gaps exist in their attitude and practice in regards to this disease. Nursing students' knowledge and attitude about epilepsy needs to improve as they provide care to epileptics. Regular organisation of awareness camps about epilepsy could be of immense help for medical students and nurses.

\section{REFERENCES}

1. Thomas SV, Nair A. Confronting the stigma of epilepsy. Ann Indian Acad Neurol 2011;14(3):158-63.

2. WHO- Epilepsy 2015 http://www.who.int/mediacentre/factsheets/fs999/en/

3. Bell G, Sander J. CPD -education and self-assessment. The epidemiology of epilepsy: the size of the problem. Seizure 2001;10(4):306-16.

4. Sridharan R, Murthy BN. Prevalence and pattern of epilepsy in India. Epilepsia 1999;40(5):631-6.

5. Leonardi M, Ustun TB. The global burden of epilepsy. Epilepsia 2002;43(Suppl 6):21-5.

6. Pahl K, de Boer HM. Epilepsy and rights. In: Atlas: Epilepsy care in the world. Geneva: WHO, 2005:72-3.

7. Goel D, Dhanai JS, Agarwal A, et al. Knowledge, attitude and practice of epilepsy in Uttarakhand, India. Ann Indian Acad Neurol 2011;14(2):116-9.

8. Sureka RK, Sureka R. Knowledge, attitude and practices with regard to epilepsy in rural north-west India. Ann Indian Acad Neurol 2007;10(3):160-4.

9. Mecarelli O, Li Voti P, Vanacore N, et al. A questionnaire study on knowledge of and attitudes toward epilepsy in schoolchildren and university students in Rome, Italy. Seizure 2007;16(4):313-19.

10. Young GB, Derry P, Hutchinson I, et al. An epilepsy questionnaire study of knowledge and attitudes in Canadian college students. Epilepsia 2002;43(6):652-8.

11. Fonseca LC, Tedrus GM, Costa AC, et al. Knowledge and attitude toward epilepsy among health area students. Arq Neuropsiquiatr 2004;62(4):1068-73.

12. Ab Rahman AF. Awareness and knowledge of epilepsy among students in a Malaysian University. Seizure 2005;14(8):593-6.

13. Hijazeen JK, Abu-Helalah MA, Alshraideh HA, et al. Knowledge, attitudes and beliefs about epilepsy and their predictors among university students in Jordan. Epilepsy \& Behavior 2014;41:238-43.

14. Falavinga A, Teles AR, Roxo MR, et al. Awareness and attitudes on epilepsy among undergraduate health care students in Southern Brazil. J Epilepsy Clin Neurophysiol 2009;15(1):19-23.

15. Kabir M, Iliyasu Z, Abubakar IS, et al. Knowledge, attitude and beliefs about epilepsy among adults in a Northern Nigerian urban community. Annals of African Medicine 2005;4(3):107-112.

16. Ekeh BC, Ekrikpo UE. The knowledge, attitude and perception towards epilepsy amongst medical students in Uyo, Southern Nigeria. Advances in Medicine Article ID 876135, 2015;2015: P. 6. 